\title{
Creativity techniques: a systematic literature review
}

\author{
Kleidson Daniel Medeiros Leopoldino, Mario Orestes Aguirre Gonzólez, Paula de Oliveira Ferreira, \\ José Raeudo Pereira, Marcus Eduardo Costa Souto \\ Universidade Federal do Rio Grande do Norte \\ e-mails: leopoldinodaniel@gmail.com; mario@ct.ufrn.br; paulaproducao@hotmail; raeudo@hotmail.com; marcus.costasouto@gmail.com
}

\begin{abstract}
Creativity techniques are one-off tools that can be used to induce the creative potential of an individual or a group of individuals for the purpose of solving problems or generating ideas in the development of new products and services. In this article, a mapping of the scientific production about the techniques of creativity was carried out in 56 scientific publications, from the search metabase Portal of Periodical Capes and Google Scholar. After analyzing the publications, we found 120 creative techniques described in the literature. Among the techniques identified, the one with the highest prevalence of citations was Brainwriting, followed by Brainstorming and Synectics. The United States, Germany and the United Kingdom concentrate the world scientific production with $70 \%$ of the publications on the subject. Regarding the methodological approach of the studies, $63 \%$ are classified as qualitative, $29 \%$ as quali-quantitative and $10 \%$ as quantitative. It was verified that more research is needed to investigate the applicability of these tools, besides the critical factors that allow the induction of the creative potential of the participants.
\end{abstract}

Keywords: systematic review, creativity techniques, non-spontaneous creativity, collective creativity.

\section{Introduction}

Before conceptualizing the techniques of creativity it is necessary to define what is creativity. For Torrance (1977), creativity is a skill that can be developed when stimulated and practiced. According to Amabile et al. (1996), when creativity is induced it can generate original, appropriate and useful products or responses, as well as being assertive and valuable to the task at hand. For this, it needs to be exercised through techniques and strategies of thought that aid in the development of this innate potential (AMABILE, 2012).

Although there is an effort to group definitions regarding creativity, and even if we have a transdisciplinary perspective, the concepts about creativity will have different meanings (LLOVERAS MACIÁ, 2008). Thus, the general tendency among researchers is to understand this complex phenomenon as a transdisciplinary symbiosis.

Considering the definition presented on creativity, it is possible to understand what the techniques of creativity are. In an instructive way Mansfield, Busse and Kreplka (1978) propose that these techniques are tools that facilitate the creative process and that can be used as instruments for the development of creativity in creative training programs. In a study conducted by Torrance (1972) on the use of creative training in classrooms, from the analysis of 142 studies, the results showed that, on average, $72 \%$ of these training programs were successful. Yet in this study Torrance
(1972) points out that the most successful approaches seem to be those involving cognitive aspects, allied to emotional functioning, which provide adequate structure and motivation, as well as opportunities for involvement, practice and interaction with teachers and other children.

Considering the challenges in the search to solve problems and the development of new products and services, this article aims to present an overview and analysis of the creativity techniques mapped in 56 scientific publications from the systematic review.

\section{Creativity techniques: tools for problem solving and the generation of ideas}

For Arnold (1962), creativity techniques when applied consciously and repeatedly help to awaken and strengthen the creative potential of individuals. Its use demystifies creativity, as well as promoting mutual support among people in problem solving and project execution.

It is recommended that in the application of these techniques consider the critical factors and the variables to stimulate creativity (RHODES, 1961; STERNBERG; LUBART, 1991; AMABILE et al., 1996; CSIKSZENTMIHALYI, 1988; BARRON; HARRINGTON et al., 1981; GARDNER, 1988; GRUBER, 1988; WOODMAN; SAWYER; GRIFFIN, 1993). 
According to Schlicksupp (1989), there are over 100 different creativity techniques. In addition to Schlicksupp (1989), there is a study developed by Smith (1998) for which there are 172 creativity techniques, 72 more than in the previous study, divided into 50 groups of techniques.

As for the classification of creativity techniques Roozenburg and Eekeles (1995) and Schlicksupp (1989), propose their stratification into two types: associative and provocative. The techniques of provocation are based on the works developed by De Bono (1970), and are widely used to foster creativity. They differ from associative techniques, since they seek to break with the preconceived elements, while associative techniques seek in the recombination of elements to generate new ideas.

For Couger (1995), techniques can be classified as analytical or intuitive. Analytical techniques generate logical patterns of thinking that tend to follow a linear pattern or sequence of steps. These techniques take advantage of different ways of organizing information known to approach problems from new viewpoints, by means of a linear pattern or a sequence of steps. Intuitive techniques rely on a single image or symbol to provide a one-time response and jump-start solutions. In general, they skip steps of a sequence (MILLER, 1987).

To understand the use of creativity techniques it is important to consider the cognitive aspects involved in the application of these tools. For Beaudot (1979), there are two fundamental concepts regarding the types of intelligence (in terms of creativity): that of convergent intelligence and that of divergent intelligence. The first is simply called intelligence and is measured with IQ tests (intelligence based on standards, such as what is taught in schools), while the second is what makes us think outside standardized ways, which makes us doubt that 2 plus 2 are 4 . The first allows us to recognize the present, the second helps us to perceive the uncertain delimitations of the future.

Divergent thinking involves opening up unusual categories of memory to use as the basis for the idea of development. Convergent thinking involves the reorganization and integration of ideas within a domain to form a coherent whole (MUMFORD; WHETZEL; REITERPALMON, 1997). According to Coney and Serna (1995), the process of creative thinking involves merging different mental elements to produce an original and appropriate solution. For Mumford, Whetzel and Reiter-Palmon (1997), the ability to combine and reorganize memories is related to individual creative success.

Therefore, research on the process of creative thinking has focused on the generation, synthesis and modification of ideas (ENGLE; MAH; SADRI, 1997). In Figure 1, the divergent and convergent thinking model is represented. The closer to the side tips, the more divergent the thought will be and the closer it will approach the so-called "discovery area". On the other hand, the closer to the horizontal points of the more convergent square will be the thought and the more it will approach the "area of familiarity". From the balance between these two opposing thoughts is that you can come up with new and creative ideas.

\section{Research method}

This research is characterized, as far as its objectives, descriptive, because it allows to expose the theme systematizing the scenario of the existing techniques of creativity (GIL, 2009). As for the technical procedures applied, the research is classified as a review of the literature. Literature review is a reliable research approach because it is comprehensive and explicitly presents the means used and the results obtained. Regarding its approach, it is considered qualitative, since it seeks to establish meaning and significance to the object of study (CRESWELL, 2007).

\subsection{Research procedure}

The study was conducted in 4 steps. In the first stage, the research problem was defined as: "What creativity techniques were addressed in scientific studies published up to the year 2015?".

For the definition of the problem, the Portal of Periodical CAPES tool was used, in which articles were selected from the key word: "Creativity Techniques", obtaining as a return 50 articles that contained in their titles this term. No selection mechanism was used to limit the reference year of the articles, thus, all publications up to december 2015

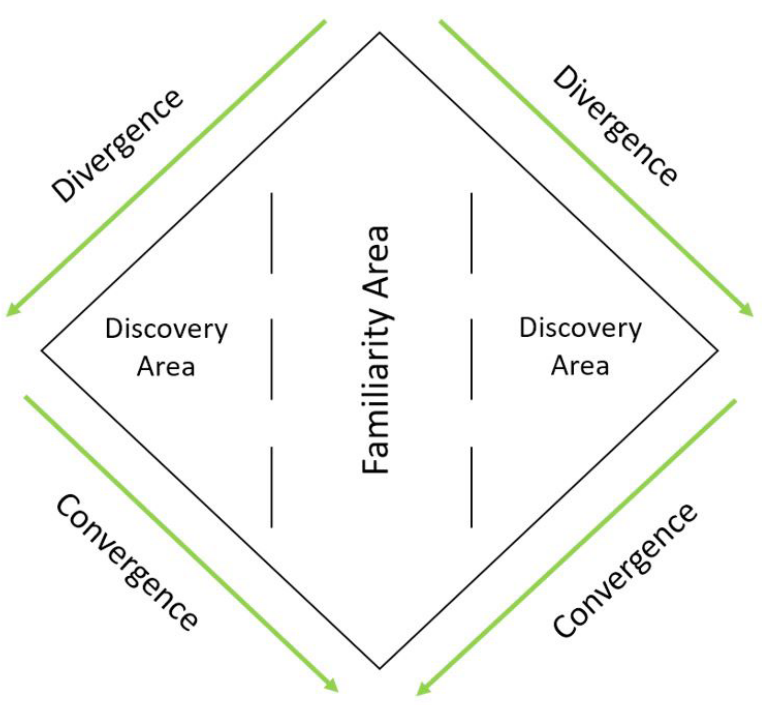

Figure 1. Divergent and convergent model of idea generation. Source: Adapted from Puccio, Murdock and Mance (2005). 
were considered in this research. In addition to this portal, an investigation was carried out in the Google Scholar database through the terms "creativity techniques" and "thesis". After the application of this filter, 6 theses were selected.

In the third stage of the research, from the complete reading of the texts, the classification of the same ones in terms of its structure and content was carried out, through the elaboration of a database in spreadsheet in the program microsoft excel. Through this, it was possible to gather the data, so that their analysis was facilitated.

After the classification phase, the considerations in the texts were analyzed, in the fourth stage, in order to verify the most cited techniques of creativity, the countries, universities and journals that have the largest number of publications on the subject, besides analyzing the methodological approach to the study of the subject in question.

\section{Results}

From the analysis of the articles, it was identified that, between the years 1997 to 2012, the greatest number of scientific publications on the subject occurred with four to five published works, respectively. The analysis also made it possible to observe that the United States with (29\%), United Kingdom with (24\%) and Germany with (17\%) are the main nations where research has been out on the subject of "creativity techniques". Fourth and fifth place are Finland and Austria with 5\% each and the other countries with values below $3 \%$.

Regarding the approach of the analyzed studies, 63\% are classified as Qualitative, 29\% as Quali-Quantitative and $10 \%$ as Quantitative. The universities that play a major role in the study of creativity techniques are of relevance: City University London, University of Oklahoma, Texas A \& M International University, University of Waikato, University of Colorado at Colorado Springs and Technical University Darmstadt.

With regard to the Journals with the highest prevalence in the publications on creativity techniques, the following stand out: Creativity and Innovation Management, Journal and Magazines> IEEE Software and the Journal of Management Development followed by the Journal of Management in Engineering.

In the mapping performed in this research 120 creativity techniques were identified. Due to its wide popularization in the most diverse organizational contexts, the creativity technique with the greatest predominance of citations in the analyzed works was the Brainwriting created by Rohrbach (1969), followed by the Brainstorming created by Osborn (1963) and the technique Synectics created by Gordon (1961), as shown in Table 1.

For the analysis, the creativity techniques were classified from six characteristics: application, type of thinking, average time for sessions, operation criteria, material
Table 1. Most cited creativity techniques.

\begin{tabular}{|c|c|c|}
\hline $\begin{array}{c}\text { CREATIVITY } \\
\text { TECHNIQUES }\end{array}$ & AUTHOR & $\begin{array}{c}\text { NUMBER OF } \\
\text { CITATIONS }\end{array}$ \\
\hline Storyboarding & Vance (1982) & 2 \\
\hline $\begin{array}{c}\text { Morphological } \\
\text { Analysis }\end{array}$ & Zwicky (1969) & 3 \\
\hline Lateral Thinking & De Bono (1970) & 4 \\
\hline TRIZ & Altshuller (1984) & 5 \\
\hline Six Thinking Hats & De Bono (1970) & 5 \\
\hline Force field analysis & Lewin (1947) & 5 \\
\hline Synectics & Gordon (1961) & 13 \\
\hline Brainstorming & Osborn (1963) & 23 \\
\hline Brainwriting & Rohrbach (1969) & 28 \\
\hline
\end{tabular}

resources and approach. The characteristic application refers to its use whether individually or in a group. The type of thought approaches which style of thought is mobilized in the creative session (divergent or convergent) and is related to the solution of problems proposed by (MUMFORD; WHETZEL; REITER-PALMON, 1997).

The average session time refers to the time spent in each creative session. The operation criteria allude to how ideas are worked out in the creative sessions (whether by exploration, combination, transformation and/or validation). Material resources are the materials used for the creative process. The approach refers to the classification of creativity techniques from the categorizations of Couger (1995) and Schlicksupp (1989).

The analysis of the techniques made it possible to observe that all have as their main purpose the application in groups, among the nine, four do not apply for individual use, Storyboarding (VANCE, 1982), Synetics (GORDON, 1961), Brainwriting (ROHRBACH, 1969) And Lateral Thinking (DE BONO, 1970). As for the use of convergent thinking, only the Lateral Thinking technique (DE BONO, 1970) does not use it. As for the use of divergent thinking three techniques do not use it, these are Morphological Analysis (ZWICKY, 1969), TRIZ (ALTSHULLER, 1984) and Force Field Analysis (LEWIN, 1947).

As for the average time of application of creativity techniques, five have no time limit for their application: Synetics (GORDON, 1961), Morphological Analysis (ZWICKY, 1969), TRIZ (ALTSHULLER, 1984), Lateral Thinking, 1967) and Force Field Analysis (LEWIN, 1947). For other techniques, the application time varies from 10 minutes to 60 minutes. According to Amabile (2012), time is an important factor for creative performance. As a general rule, it is suggested that there is little or moderate pressure of this factor, but occasionally there should be periods that arouse a sense of urgency in the participants in the creative process. 


\begin{tabular}{|c|c|c|c|c|c|c|}
\hline 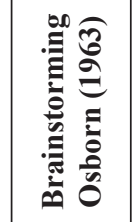 & 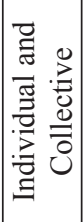 & 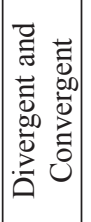 & $\begin{array}{l}. \dot{\Xi} \\
\vdots \\
0 \\
0 \\
0 \\
0\end{array}$ & 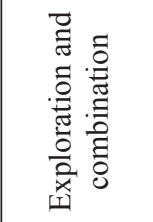 & 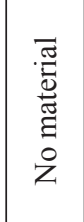 & 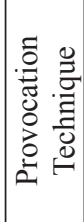 \\
\hline 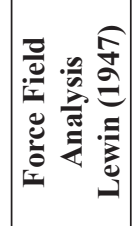 & 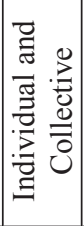 & 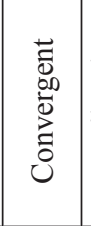 & 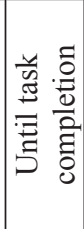 & 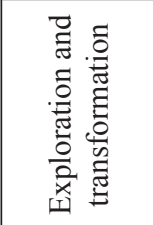 & 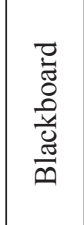 & 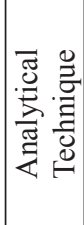 \\
\hline 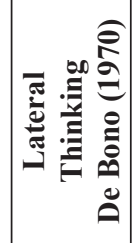 & 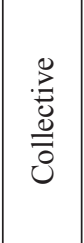 & $\begin{array}{l}\overrightarrow{D_{0}} \\
\dot{0} \\
\stackrel{\overrightarrow{0}}{0} \\
0\end{array}$ & 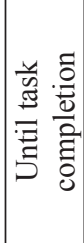 & 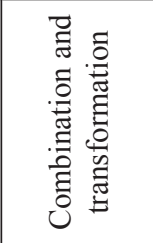 & 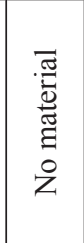 & 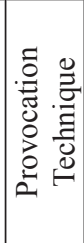 \\
\hline 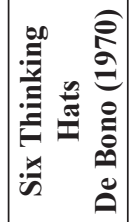 & 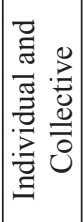 & 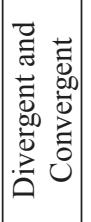 & $\begin{array}{l}\dot{\Xi} \\
\dot{\Xi} \\
8\end{array}$ & 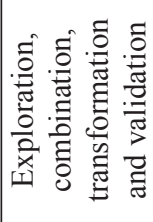 & 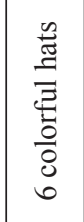 & 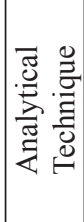 \\
\hline 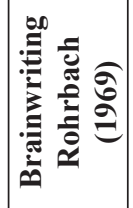 & 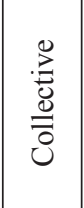 & 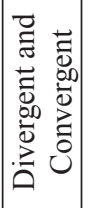 & 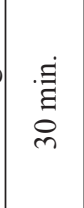 & 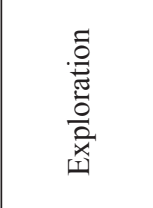 & $\begin{array}{l}\frac{n}{0} \\
\frac{\tilde{U}}{n} \\
\frac{u}{\tilde{E}} \\
\frac{\pi}{n}\end{array}$ & 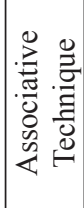 \\
\hline 늘 & 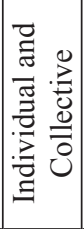 & $\begin{array}{l}\overrightarrow{\tilde{D}_{0}} \\
\dot{0} \\
\overrightarrow{0} \\
0 \\
0\end{array}$ & 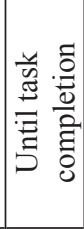 & 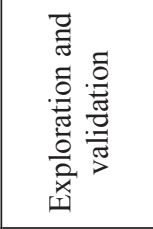 & 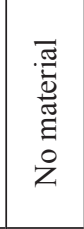 & 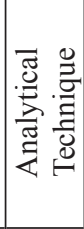 \\
\hline 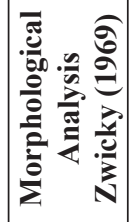 & 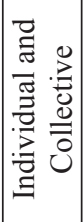 & 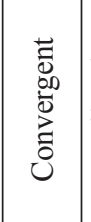 & 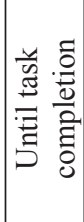 & 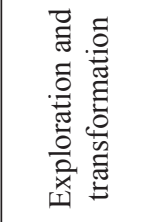 & 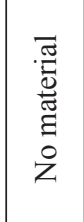 & 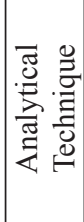 \\
\hline 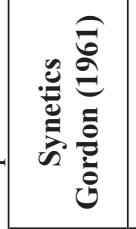 & $\begin{array}{l}\stackrel{2}{0} \\
\stackrel{0}{0} \\
\overline{0}\end{array}$ & 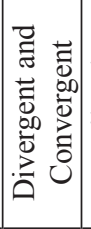 & 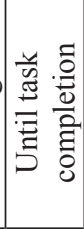 & 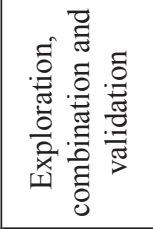 & 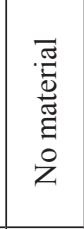 & 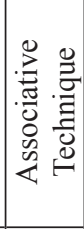 \\
\hline 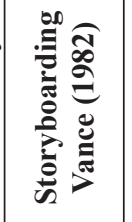 & 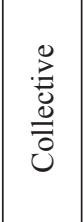 & 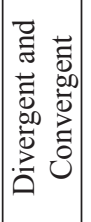 & 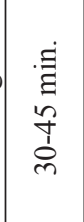 & 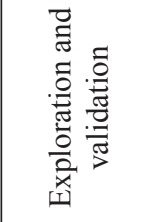 & Ũ⿱艹⿹勹巳 & 疍疍 \\
\hline 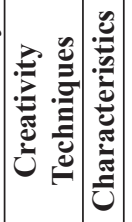 & 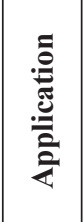 & 资 & 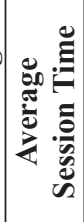 & Uُّ & 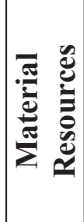 & \\
\hline
\end{tabular}


The criteria for the operationalization of creativity techniques were represented in four groups: exploration, combination, validation and transformation. The only technique to use the four criteria is Six Thinking Hats (DE BONO, 1985), the Synetics technique (GORDON, 1961) used three criteria and the others between one or two criteria. Material resources are generally easy to access (cards, slates, sheets of paper), since it is important that the resources required for the application of the technique are not difficult to find on a daily basis.

Finally, it was observed the predominance of techniques classified as analytical and the tie between associative and provocation techniques. Table 2 below compiled such information to facilitate an understanding of the results achieved.

\section{Final considerations}

Since the human evolutionary process, creativity has been and continues to be the key not only for survival, but also for human progress. Creativity seen as an inherent potential of the human condition must be worked out to become a useful skill for individuals and society. Thus, techniques that develop this capacity both individually and collectively (within groups and organizations) need to be understood to be better applied.

In the case of the creative process in organizations, there is evidence of the influence of the physical environment as well as of the psychological environment - created through an organizational culture - as facilitating resources of creativity (GEIS, 1988). Therefore, studies relevant to this field deal with individual and collective processes, especially when discussing creative techniques.

Such techniques make it possible to promote the generation of ideas as a source for innovation in organizations, although some adaptation to the characteristics of the organization, type of innovation and the work team among other factors is required. Therefore, there is a need for research regarding the implementation and improvement of these tools with teams of ideation and / or innovation.

Finally, it is worth emphasizing that it is necessary to reflect on the usefulness of these tools and the interferences that the stimulating factors of creativity present in their approaches can influence in the application of creativity techniques.

\section{References}

ALTSHULLER, G. S. Creativity as an exact science: the theory of the solution of inventive problems. New York: Gordon and Breach, 1984.

AMABILE, T. M. Componential theory of creativity. Boston: Harvard Business School, 2012. Harvard Business School Working Paper, n. 12-096.
AMABILE, T. M. et al. Assessing the work environment for creativity. Academy of Management Journal, v. 39, p. 1154-1184, 1996.

ARNOLD, J. E. Useful creativity techniques. In: PARNES, S. (Ed.). Sourcebook for creative thinking. New York: Charles Scribner's Sons, 1962. p. 127-138.

BARRON, F.; HARRINGTON, D. M. Creativity, intelligence, and personality. Annual Review of Psychology, v. 32, p. 439-476, 1981.

BEAUDOT, A. Vers une pédagogie de la créativité. Paris: Les éditions ESF, 1979. p. 125.

CONEY, J.; SERNA, P. Creative thinking from an information processing perspective: a new approach to mednick's theory of associative hierarchies. The Journal of Creative Behavior, v. 29, p. 109-130, 1995.

COUGER, J. D. Creative problem solving and opportunity finding. Danvers: Mass., Boyd \& Fraser Pub., 1995.

CRESWELL, J. W. Projeto de pesquisa: métodos qualitativo, quantitativo e misto. $3^{\mathrm{a}}$ ed. Porto Alegre: Artmed, 2010.

DE BONO, E. Lateral thinking: creativity step by step. New York: Harper \& Row, 1970.

ENGLE, D. E.; MAH, J. J.; SADRI, G. An empirical comparison of entrepreneurs and employees: Implications for innovation. Creativity Research Journal, v. 10, n. 1, p. 45-49, 1997. http://dx.doi.org/10.1207/s15326934crj1001_5.

GARDNER, H. Creativity: a interdisciplinary perspective. Creativity Research Journal, v. 1, p. 8-26, 1988.

GEIS, G. T. Making companies creative. In: KUHN, R. L (Ed.). Handbook for creative and innovative managers. New York: McGraw-Hill, 1988. p. 25-33.

GIL, A. C. Como elaborar projetos de pesquisa. 4. ed. São Paulo: Atlas, 2009.

GORDON, W. J. J. Synectics: the development of creative capacity. New York: Harper \& Row, 1961.

GRUBER, H. E. The envolving systems approach to creative work. Creativity Research Journal, v. 1, p. 27-59, 1988.

LEWIN, K. Frontiers of group dynamics. Human Relations, v. 1, p. 5-41, 1947.

LLOVERAS MACIÁ, J. Creatividad para la innovación y la complejidad de los productos industriales. Encuentros Multidisciplinares, n. 29, v. 10, 2008.

MANSFIELD, R. S.; BUSSE, T. V.; KREPLKA, E. J. The effectiveness of creativity training. Review of Educational Research, v. 48, p. 517-536, 1978.

MUMFORD, M. D.; WHETZEL, D. L.; REITER-PALMON, R. Thinking creatively at work: organization influences 
on creative problem solving. The Journal of Creative Behavior, v. 31, n. 1, p. 7-17, 1997.

OSBORN, A. F. Applied imagination. $3^{\text {rd }}$ ed. New York: Scribner, 1963.

PUCCIO, G. J.; MURDOCK, M. C.; MANCE, M. Current developments in creative problem solving for organizations: a focus on thinking skills and styles. Korean Journal of Thinking \& Problem Solving, v. 15, p. 43-76, 2005.

RHODES, M. Analysis of creativity. Phi Delta Kappan, v. 42, n. 7, p. 305-310, 1961.

ROHRBACH, B. Creative by rules - method 635, a new technique for solving problems. Absatzwirtschaft, v. 12, p. 73-53, 1969.

ROOZENBURG, N. F. M.; EEKELES, J. Product design: fundamentals and methods. Chichester: Wiley, 1995.

SCHLICKSUPP, H. Innovation, Kreativität und Ideenfindung. Würzburg: Vogel, 1989.
SMITH, G. F. Idea-generation techniques: a formulary of active ingredients. The Journal of Creative Behavior, v. 32, n. 2, p. 107-133, 1998.

STERNBERG, R. J.; LUBART, T. I. An investment theory of creativity and its development. Human Development, v. 34, p. 1-31, 1991.

TORRANCE, E. P. Can we teach children to think creatively? The Journal of Creative Behavior, v. 6, p. 114-143, 1972.

TORRANCE, E. P. Creativity in the classroom. Washington: National Education Association, 1977.

VANCE, M. Storyboarding. In: VANCE, M. Creativity. Illinois: Nightengale-Conant, 1982.

WOODMAN, R. W.; SAWYER, J. E.; GRIFFIN, R. W. Toward a theory of organizational creativity. Academy of Management Review, v. 18, p. 293-321, 1993.

ZWICKY, F. Discovery invention, research through the morphological approach. New York: Macmillan, 1969. 